\title{
SECOND RECORD OF THE COBIA, RACHYCENTRON CANADUM (ACTINOPTERYGII: PERCIFORMES: RACHYCENTRIDAE), FROM THE MEDITERRANEAN SEA
}

\author{
Okan AKYOL* and Vahdet ÜNAL \\ Ege University Faculty of Fisheries, Urla, Izmir, Turkey
}

\begin{abstract}
Akyol O., Ünal V. 2013. Second record of the Cobia, Rachycentron canadum (Actinopterygii: Perciformes: Rachycentridae), from the Mediterranean Sea. Acta Ichthyol. Piscat. 43 (4): 315-317.

Abstract. On 2 August 2013, a specimen of the cobia, Rachycentron canadum (Linnaeus, 1766), was caught off Marmaris, south-eastern Aegean coast of Turkey. The fish was examined and morphometric characteristics of the specimen collected were determined. The species is being reported from the second time in the Mediterranean, preceded by its first occurrence off Haifa, Israel in 1978. The newly caught specimen was larger (SL) than the previously recorded individual $(923 \mathrm{~mm}$ vs. $766 \mathrm{~mm}$ ). All measurements, counts, and colour patterns determined were consistent with earlier published descriptions of the species.
\end{abstract}

Keywords: Rachycentron canadum, cobia, Lessepsian migration, Mediterranean

Cobia, Rachycentron canadum (Linnaeus, 1766) is a large, migratory, pelagic fish of the monotypic family Rachycentridae, which are found mainly close to the shore with the depth range of $0-1200 \mathrm{~m}$. The young fish are mainly solitary, which later become gregarious (Golani et al. 2006, Froese and Pauly 2013). Cobia has been observed occurring over a variety of bottom types, such as: mud, sand and gravel, coral reefs; off rocky shores and in mangrove sloughs; inshore around pilings and buoys, and offshore around drifting and stationary objects; occasionally in estuaries (Froese and Pauly 2013). They feed on pelagic and benthic fish, crustacean (especially crabs, so called 'crabeater') and cephalopods (Golani et al. 2002, 2006). Cobia is considered an excellent game fish (Golani et al. 2002).

Cobia adults reach lengths of up to $2 \mathrm{~m}$ and weights of $68 \mathrm{~kg}$ (Froese and Pauly 2013) and due to its rapid growth, it has been an excellent candidate for aquaculture with research on spawning and grow-out has been underway in Taiwan and the USA since the early 1990s; PR China, Vietnam, and the Philippines are currently farming cobia in cages and recently research and production have been initiated in the EU, Brazil, and Panama. To date, research and development of cobia aquaculture has been initiated in over 23 countries, half of which reside in the Asian-Pacific region (Holt et al. 2007, Nhu et al. 2011). Cobia is initially reared in outdoor and subsequently transferred to open ocean cages grow to 6-10 kg within 1-1.5 years (Liao et al. 2004).

Cobia is distributed nearly worldwide in tropical and subtropical waters, except for the central and eastern Pacific, covering the areas: from Canada to Bermuda and
Massachusetts; from USA to Argentina, including the Gulf of Mexico and entire Caribbean in Western Atlantic; from Morocco to South Africa in Eastern Atlantic and East Africa and Hokkaido; from Japan to Australia in Indo-West Pacific (Tortonese 1986, Shaffer and Nakamura 1989, Golani et al. 2006, Froese and Pauly 2013). In the Mediterranean Sea, only a single specimen was recorded in Haifa Bay, Israel in 1978 (Golani and Ben-Tuvia 1986).

On 2 August 2013, a specimen of Rachycentron canadum (Fig. 1) was caught by a longline fisherman targeting grouper on a boat from which sardine and squid flesh was used as bait. The fish snapped the bait at the surface of the sea while the fisherman was hauling the longline (diameters of main and branch line were $0.9 \mathrm{~mm}$ and $0.8 \mathrm{~mm}$, respectively). Location of the capture was the Marmaris coast $\left(36^{\circ} 42^{\prime} \mathrm{N}-28^{\circ} 15^{\prime} \mathrm{E}\right)$, South-eastern Aegean Sea (Fig. 2), at the depth of $30-50 \mathrm{~m}$ on a sandy bottom. The specimen was fixed in $4 \%$ formaldehyde solution and deposited in the fish collection of the Ege University, Fisheries Faculty (ESFM-PIS/2013-002). Diagnostic characters were counted and recorded.

The specimen measured $923 \mathrm{~mm}$ standard length (SL, and $10826 \mathrm{~g}$ weight); the percentage of SL to fork and total lengths were $107.5 \%$ and $119.3 \%$, respectively. The ratio head length (HL) to SL was $21.9 \%$, while the pre-dorsal length accounted for $24.8 \%$ of SL, the pre-anal length $55.3 \%$ of SL, pre-pectoral length $22.3 \%$ of SL, and maximum body depth $17.3 \%$ of SL. Based on the HL, the eye diameter was $9.4 \%$ and pre-orbital length $42.6 \%$. In percentage of HL: eye diameter $13.3 \%$, pre-orbital length $38.7 \%$ and inter-orbital length $52.5 \%$. The meristics

\footnotetext{
${ }^{*}$ Correspondence: Dr. Okan Akyol, Ege Üniversitesi, Su Ürünleri Fakültesi, 35440 Urla, Izmir, Turkey, phone: (+90) 232 7521162, fax: (+90) 232 3747450, e-mail: okan.akyol@ege.edu.tr.
} 
of fins were: dorsal fin rays VIII +32 , anal fin rays III +23 , Atlantic origin is also possible. Golani and Sonin (1996) pectoral fin rays 20 , and ventral fin rays $\mathrm{I}+5$. All measure- debated that the occurrence of some tropical eastern ments, counts, and colour patterns determined were in accor- Atlantic species in the Levant is reasonable and do not repdance with of Tortonese (1986), Shaffer and Nakamura (1989), Golani et al. (2006), and Froese and Pauly (2013). resent isolated populations but rather a sparsely continuous distribution. Although, distribution of some common fish-

The specimen caught from Marmaris was larger (923 mm es such as_Epinephelus haifensis (Ben-Tuvia, 1953); SL) than the previously recorded individual (766 mm SL, Sphyraena viridensis Cuvier, 1829; Acanthurus monroviGolani and Ben-Tuvia, 1986).

According to Golani et al. (2002), the mode of introae Steindachner, 1876; Arius parkii Günther, 1864

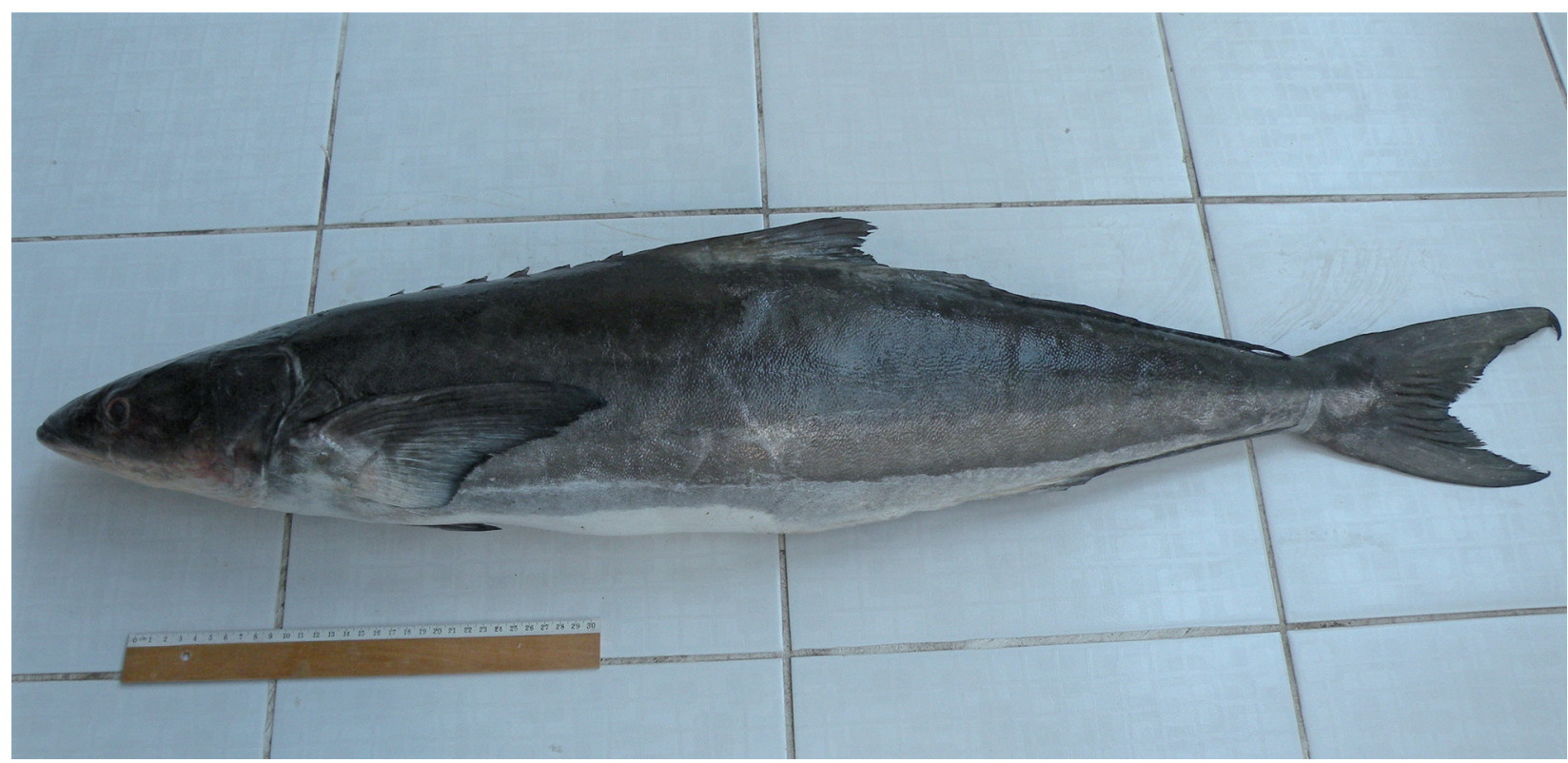

Fig. 1. Cobia, Rachycentron canadum, caught off Marmaris, SE Aegean, Turkey, 923 mm SL

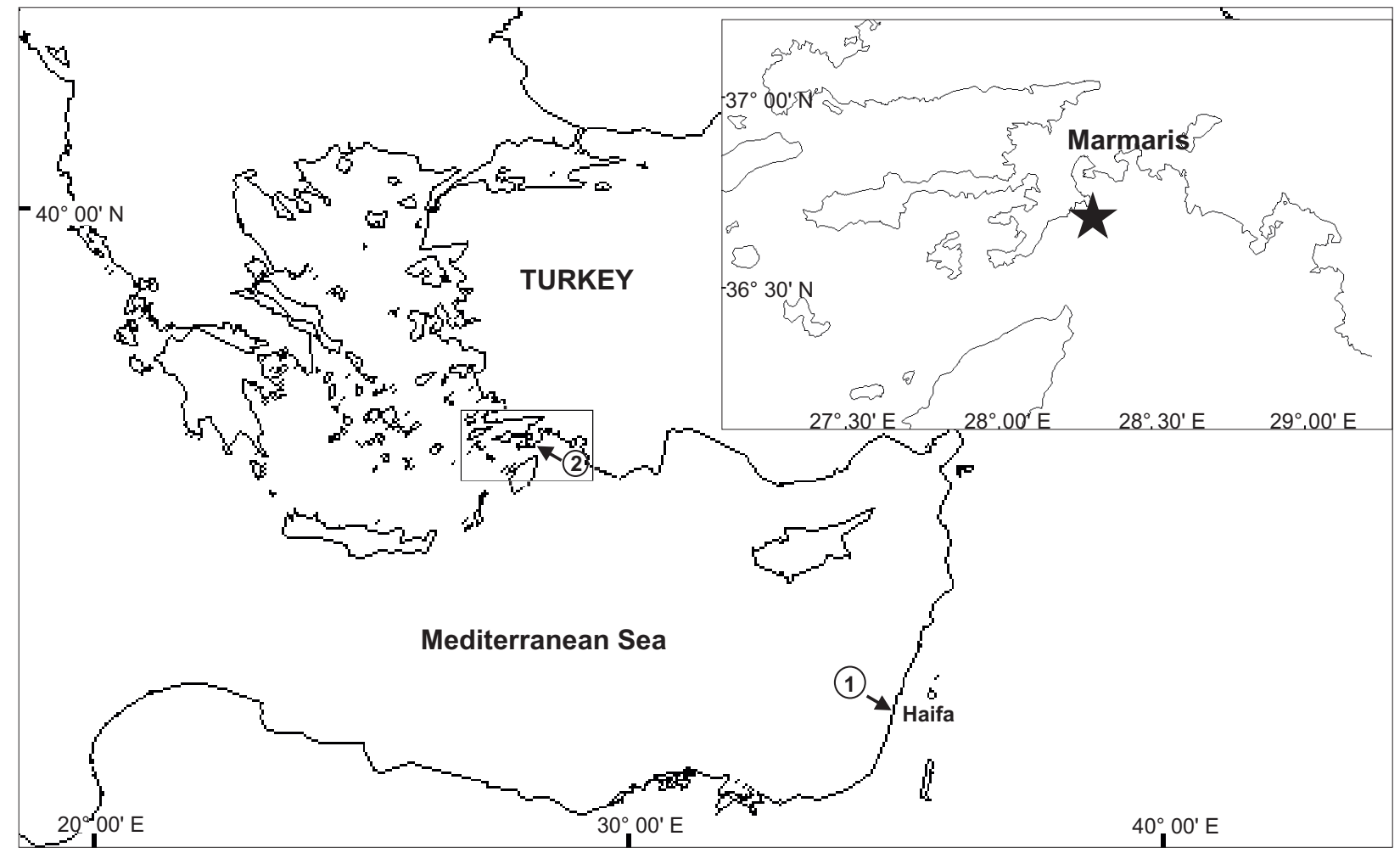

Fig. 2. Records of cobia, Rachycentron canadum, in the Mediterranean Sea: 1 = Haifa, Israel, 10 November 1978 , 2 = Marmaris, Turkey 2 August 2013 
record in the Mediterranean Sea was considered to be a Lessepsian migrant by Golani and Ben-Tuvia (1986). In that case, the second record from Turkey shows that an introduction to the Levantine basin via Suez Canal is rational, because there has been no record from the western basin of the Mediterranean so far.

The occurrence of Rachycentron canadum in Marmaris, south-east Aegean Sea was not unexpected but did not clearly indicate an established population. However, this short report contributes to the knowledge of a new Lessepsian fish for the Turkish ichthyofauna.

\section{ACKNOWLEDGEMENTS}

The authors express sincere thanks to Dr. Mark Dimech for English editing, and Mesut Güven, Director of the Marmaris Fishery Cooperative, Mehmet Yasar, fisherman who caught the fish, for their cooperation.

\section{REFERENCES}

Froese R., Pauly D. (eds.) 2013. FishBase. [version 04/2013] http://www.fishbase.org

Golani D., Ben-Tuvia A. 1986. New records of fishes from the Mediterranean coast of Israel including Red Sea immigrants. Cybium 10 (3): 285-291.

Golani D., Orsi-Relini L., Massuti E., Quignard J.-P. 2002. CIESM atlas of exotic species in the Mediterranean. Vol. 1. Fishes. Commission Internationale pour l'Exploration Scientifique de la Méditerranée (CIESM), Monaco.

Golani D., Öztürk B., Başusta N. 2006. Fishes of the eastern Mediterranean. Turkish Marine Research Foundation (Publication No. 24), Istanbul, Turkey.
Golani D., Sonin O. 1996. The occurrence of the tropical west African marine fishes Acanthurus monroviae (Acanthuridae) and Arius parkii (Ariidae) in the Levant. Aqua International Journal of Ichthyology 2 (1): 1-3.

Holt G.J., Faulk C.K., Schwarz M.H. 2007. A review of the larviculture of cobia Rachycentron canadum, a warm water marine fish. Aquaculture 268 (1-4): 181-187. DOI: 10.1016/j.aquaculture.2007.04.039

Liao I.C., Huang T.-S., Tsai W.-S., Hsueh C.-M., Chang S.-L., Leaño E.M. 2004. Cobia culture in Taiwan: current status and problems. Aquaculture 237 (1-4): 155-165. DOI: 10.1016/j.aquaculture.2004.03.007

Nhu V.C., Nguyen H.Q., Le T.L., Tran M.T. Sorgeloos P., Dierckens K., Reinertsen H., Kjørsvik E., Svennevig N. 2011. Cobia Rachycentron canadum aquaculture in Vietnam: Recent development and prospects. Aquaculture 315 (1-2): 20-25. DOI: 10.1016/j.aquaculture.2010.07.024

Shaffer R.V., Nakamura E.L. 1989. Synopsis of biological data on the cobia Rachycentron canadum (Pisces: Rachycentridae). NOAA Technical Report NMFS 82. FAO Fisheries Synopsis 153.

Tortonese E. 1986. Rachycentridae. P. 814. In: Whitehead P.J.P., Bauchot M.-L., Hureau J.-C., Nielsen J., Tortonese E. (eds) Fishes of the north-eastern Atlantic and the Mediterranean. Vol. 2. UNESCO, Paris, France.

Received: 7 August 2013

Accepted: 6 November 2013 Published electronically: 31 December 2013 